\title{
Effectiveness of Self-Regulated Learning Skills on Web- Based Instruction Attitudes in Online Environments
}

\author{
Hasan ÖZDAL ${ }^{1}$, Celalettin ÖZDEN, ${ }^{2}$ Ramazan ATASOY ${ }^{3}$, Ahmet GÜNEYLi ${ }^{4}$ \\ ${ }^{1}$ Engineering Faculty, Final International University, Kyrenia, Northern Cyprus, \\ ${ }^{2}$ Republic of Turkey Ministry of National Education, Famagusta, Northern Cyprus, \\ ${ }^{3}$ Education Faculty, Harran University, Şanlıurfa, Turkey, \\ ${ }^{4}$ Education Faculty, European University of Lefke, Nicosia, Northern Cyprus
}

\begin{abstract}
In this study, pre-service teachers' self-regulated learning skills in online environments were taken into consideration. Preservice teachers could not receive any support with respect to online education during the pandemic process thus they had to improve themselves. In this context, it was investigated whether self-regulated learning skills in online environments predict web-based instruction attitudes in terms of both effectiveness and resistance dimensions. Designed in the context of the quantitative research approach, this study is based on the relational survey model. The research universe is composed of the pre-service teachers studying in the Turkish and English language teaching departments of Northern Cyprus universities during the 2020-2021 academic year. In conclusion, it was found that three of the self-regulated learning skills of the participating pre-service teachers in online environments, i.e. goal setting, task strategies, and help-seeking, predicted the attitudes of the pre-service teachers towards web-based instruction significantly and in the positive direction (Hypothesis 1), whereas only two of the self-regulated learning skills of the participating pre-service teachers in online environments, i.e. goal setting and task strategies, predicted the resistance of the pre-service teachers to web-based instruction significantly and in the negative direction (Hypothesis 2).
\end{abstract}

Keywords: Efficiency, Online environments, Pandemic period, Resilience. Self-regulated learning skills, Web based instruction.

\section{INTRODUCTION}

The studies carried out during the pandemic period in Northern Cyprus have a common aspect in that the teachers and pre-service teachers either did not use or did not prefer to use web-based instruction before the pandemic. Although they had high attitudes towards web-based instruction before the pandemic, they compulsorily used it during the pandemic period and developed the skills to use web-based education environments. However their attitudes towards web-based instruction gradually became negative. In other words, the pandemic has reversed the facts about online education in that it was started to be commonly practiced across the country with the onset of the pandemic as compared to before the pandemic period during which online education was seldom practiced. The attitudes towards online education became negative as opposed to before the pandemic period during which attitudes towards online education were very positive (Atasoy, Özden and Kara, 2020; Egeli and Özdemir, 2020; Kanık, 2021; KeAB, 2021; KTÖS, 2020, Metron, 2021; Nadiahan and Cabauatan, 2021).

In view of the foregoing, in this study, it was thought that it would be necessary to investigate why attitudes towards web-based instruction became negative during the pandemic period and that the results of such a study would be valuable. In this context, in this study, the attitudes of pre-service teachers in Northern Cyprus towards web-based instruction were analyzed and evaluated in detail in order to reveal the factors that affect the attitudes towards web-based teaching-learning activities and contribute to the literature as such.
The conceptual framework of this study is addressed under two categories; web-based instruction and attitudes towards web-based instruction, and self-regulated learning skills in online environments.

The development of technology and the widespread use of the internet have created the need for individuals to access information faster and easier. The internet environment, where the production and sharing of information is extremely easy, greatly contributed to the educational processes. Individuals prefer learning in the internet environment as they can access information irrespective of time and place (Horzum and Balta, 2008). In today's world, internet-based applications are widely used by all segments of society, starting from very young age groups to adults, via computers and mobile devices (Yasakc1 and Özdal, 2019). The intensive use of online technologies and

Corresponding Author e-mail: aguneyli@eul.edu.tr

https://orcid.org/0000-0002-2168-1795

How to cite this article: ÖZDAL $H$, ÖZDEN C, ATASOY R, GÜNEYLI A (2022). Effectiveness of Self-Regulated Learning Skills on WebBased Instruction Attitudes in Online Environments. Pegem Journal of Education and Instruction, Vol. 12, No. 1, 2022, 182-193

Source of support: Nil

Conflict of interest: None.

DOI: 10.47750/pegegog.12.01.18

Received: 19.09.2021

Accepted: 12.12.2021 Publication: 01.01.2022 
new approaches in education have popularized the concept of web-based instruction (Akgün, 2018; Muhametjanova and Akmatbekova, 2019). Web-based learning, on the other hand, can be defined as learning carried out in environments that support and accelerate the teaching carried out using educational software on the internet (Smith, 2006). The use of web-based instruction both stand-alone or in combination with conventional learning methods have become widespread throughout the world through virtual applications such as virtual course contents, virtual reality, various virtual presentation tools, synchronous or asynchronous e-conference systems, simulation, etc. (Venkatesh and Sathyalakshmi, 2020).

These changes and innovations experienced in general education processes naturally reflected on teacher training institutions and provided the spread of research on web-based instruction in teacher education (Scull, Phillips, Sharma, \& Garnier, 2020; Verma, Campbell, Melville, \& Park, 2020; Carrillo \& Flores, 2020; Gupta \& Pathania, 2021). In the researches, it is seen that web-based instruction has some limitations besides its advantages. Simonson, Smaldino, Albright and Zvacek, (2012) stated that web based instruction offers an important opportunity for individuals who cannot attend classes due to time and place problems or who feel the need to improve themselves in subjects they are interested in individually. Kaya (2006) states that web based instruction is an attractive system in terms of generating an important solution to inequality of opportunity, providing lifelong education opportunities to individuals when needed, contributing to the fulfillment of social and individual goals, benefiting from educational technologies, and gaining self-learning skills. In parallel with this information, Bakioğlu and Can (2014) stated that web based learning, which offers learners an independent and flexible learning environment, contributes to the spread of lifelong learning. Distance education, especially with the support of developing web-based platforms and technologies, provides individuals with educational environments independent of time and place (Bilgiç \& Tüzün, 2015). With these features, distance education provides the opportunity to complete and reinforce the missing information in different time periods in accordance with the learning speed of the students (Gregory \& Lodge, 2015).

Some limitations of web-based instruction have also been emphasized in the researches. Shandra \& Chystiakova (2021) stated that synchronous and asynchronous web-based education have limitations such as; internet addiction, difficult to control a group of many students, unexpected disconnection of participants, requires intensive study time for teachers, lack of flexibility in terms of time, limited socialization and communication, lack of personal interaction among students, difficulties in developing knowledge and skills based on practice. Similarly, according to the study conducted by Mukhtar, Javed, Arooj \& Sethi (2020), it was stated that online education have limitations such as; teaching practice-based knowledge and skills, it is difficult to give immediate feedback, continuous attention and focus is not possible, and students access online resources by misbehaving in the evaluation processes In the study conducted by Mercier, Scholten, Baltensperger, Gremaud, \& Dabros (2021), it was emphasized that the use of digital tools and equipment in online education can be difficult for both teachers and students, requires more time and workload, and education can be disrupted due to technical problems. According to the study conducted by Štefančík \& Stradiotová (2021), while it was stated that the biggest problem in online education is socialization, it was emphasized that the teachers could not provide enough control in the evaluation processes, and the limitations of the disruption of education in the absence of sufficient equipment.

As was the case in the studies presented above, learners' attitudes towards web-based instruction processes have been generally addressed in the following dimensions; "effectiveness" of web-based instruction, and "resistance" to web-based instruction. Studies that investigated the effectiveness of web-based instruction focused on learners' attitudes towards the efficiency of web-based education systems (Ni, 2013; Aji et al., 2018), whereas the studies that investigated the resistance to web-based instruction focused on the ability to adapt positively in the face of difficulties (Simons, Beaumont, \& Holland, 2018).

Contemporary learning and teaching theories emphasize the importance of students knowing how to regulate their learning effectively. It was demonstrated in numerous studies that effective regulation of learning is crucial for success (Lawson et al., 2019). Self-regulated learning is defined not as an ability such as intelligence or academic ability or reading proficiency, but as a self-directed process in which learners transform their mental abilities into academic skills (Aydoğan, 2018; Zimmerman, 2005; Zheng, Li and Chen, 2016). In other words, self-regulated learning is a process that helps students manage their thoughts, behaviors and emotions in order to successfully guide their learning experiences (An, Wang, li, Gan and Li, 2021; Jarvela and Jarvenoja, 2011).

It is important to consider the profile of the learner with self-regulated learning skills in understanding and correctly interpreting the concept of self-regulated learning. Zimmerman and Schunk (2011) stated that individuals with self-regulated learning skills set their own goals and strive to reach these goals. Similarly, An, Gan and Wang, (2020) and Wolters, Pintrich and Karabenick (2003) stated that individuals with self-regulated learning skills can control their cognitive processes, motivational beliefs and behaviors in line with the goals they set, and make adjustments when necessary. According to Moos and Bonde (2016), individuals with self-regulated learning skills are aware of the behaviors they can perform and can evaluate their performances 
Table 1: Self-Regulated Learning Skills (Zimmerman, 2013)

\begin{tabular}{ll}
\hline Goal Setting & $\begin{array}{l}\text { In this dimension, educational goals and the related sub-goals are determined, and the planning skills to } \\
\text { sequence, schedule and complete the activities in respect to these goals are addressed. }\end{array}$ \\
Structuring the Environment & $\begin{array}{l}\text { In this dimension, the skills to choose the most suitable physical environment to facilitate learning or making } \\
\text { the necessary arrangements to provide such an environment are addressed. }\end{array}$ \\
Task Strategies & In this dimension, goal setting and strategic planning skills are addressed. \\
Time Management & $\begin{array}{l}\text { This dimension focuses on the learners' ability to plan and schedule activities in the course of learning } \\
\text { process and to use time effectively and efficiently. }\end{array}$ \\
Thelp-seeking & $\begin{array}{l}\text { This dimension focuses on the learners' approach towards seeking help from peers and teachers in the face } \\
\text { of a problem experienced during the course of the learning process. }\end{array}$ \\
Self-regulation & In this dimension, student's self-management (reward, punishment, etc.) skills in case of success or failure \\
are addressed.
\end{tabular}

related thereto by themselves. In addition, these individuals also observe themselves in learning environments, see their deficiencies, and make an effort to correct them (Moos \& Bonde, 2016).

A review of the relevant studies available in the literature revealed that self-regulated learning skills are generally examined under 6 dimensions. These dimensions are given in Table 1.

There are many studies available in the literature in which the factors affecting self-regulated learning skills have been investigated. To give a few examples; in the study conducted by Lin, Huang, and Chuang (2015) a strong relationship was found between self-regulated learning skills and online learning; whereas in the study conducted by Bradley, Browne and Kelley (2017), self-regulated learning skills were found to have a predictive effect on the academic achievement of learners in both online learning environments and traditional learning environments.

Accordingly, in this study, pre-service teachers' selfregulated learning skills in online environments were taken into consideration in particular, as they could not receive any support concerning online education during the pandemic process and had thus to improve themselves to that effect. In this context, it was investigated whether self-regulated learning skills in online environments predict web-based instruction attitudes in terms of both effectiveness and resistance dimensions.

\section{Purpose}

The population of this study comprised pre-service teachers, as it was assumed that pre-service teachers would be able to approach web-based instruction both from students' point of view as they assume the role of a student during the pandemic process, and from teachers' point of view as they assume the role of a teacher in the future. The research questions that were determined in line with the aim of this study are as follows:

- To what extent do the pre-service teachers' scores on the sub-dimensions of self-regulated learning skills in online environments predict the effectiveness of web-based instruction?

- To what extent do the pre-service teachers' scores on the sub-dimensions of self-regulated learning skills in online environments predict the resistance to web-based instruction?

It is the hypothesis of the authors of this study that the self-regulated learning skills of the pre-service teachers, who participate in the study, in online environments, will affect the attitudes of the pre-service teachers towards web-based instruction significantly and in the positive direction (Hypothesis 1) and predict the resistance to webbased instruction significantly and in the negative direction (Hypothesis 2).

\section{Method \\ Research Design}

Designed in the context of the quantitative research approach, this study is based on the relational survey model. Survey models are research approaches that aim to describe a past or present situation as it happens (Büyüköztürk, Çokluk, \& Köklü, 2014). The relational survey model, on the other hand, is a research model that focuses on determining the existence or degree of change between two or more variables (Karasar, 2018), and aims to describe the views and qualities of the masses. In this study, a research model was created to test the effect of sub-dimensions of pre-service teachers' online self-regulated learning behaviors on web-based instruction attitude of pre-service teachers. The dependent and independent variables of the research are presented in Figure 1.

As seen in Figure 1, the sub-dimensions of pre-service teachers' online self-regulated learning behaviors (i.e. Goal setting, Structuring the Environment, Task Strategies, Time Management, Help-seeking, and Self-Regulation) were studied as independent variables, with the sub-dimensions of web-based instruction attitude of pre-service teachers (i.e. Efficiency of Web Based Instruction and Resilience of Web Based Instruction) as dependent variables. 


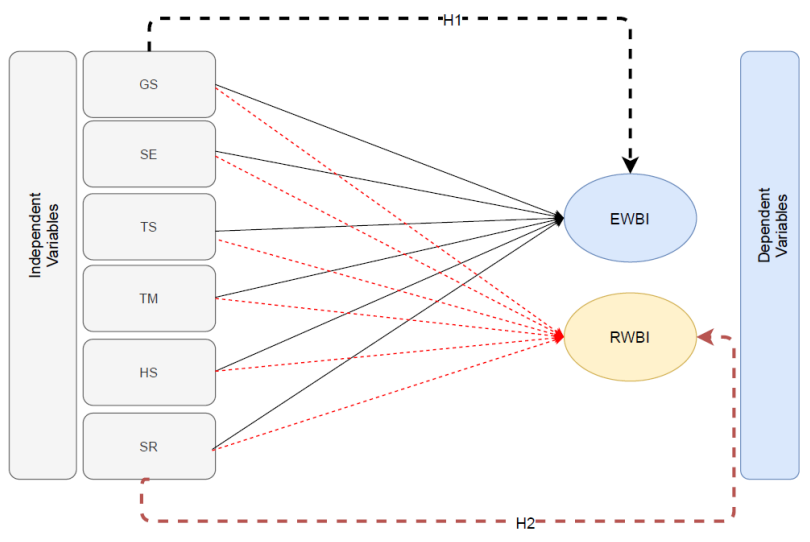

Figure 1: Research Design

\section{Study Group}

The research universe is composed of the pre-service teachers studying in the Turkish and English language teaching departments of Northern Cyprus universities during the 20202021 academic year. Within the scope of the research, data was collected from the pre-service teachers of the European University of Lefke, Eastern Mediterranean University, Final International University, University of Kyrenia, Girne American University, American University of Cyprus, Cyprus Science University, Social Sciences University of Ankara, Middle East Technical University Northern Cyprus Campus, Cyprus International University, Near East University, and Cyprus Island City University. The participants were attended by way of simple random sampling method assuming that every part of the universe had an equal chance to join in the sample group (Büyüköztürk, Çakmak, Akgün, Karadeniz, \& Demirel, 2016). A total of 384 participants were picked from the universe, and all participants volunteered to participate in the research.

\section{Data Collection Tools}

Online Self-Regulated Learning Scale (OSRLS): The scale was originally developed by Barnard, Lan, To, Paton and Lai (2009), and was adapted into Turkish language by Korkmaz and Kaya (2012). The scale was designed in the five-point Likert style, and consists of six sub-dimensions, which are Goal Setting [GS; five items], Structuring the Environment [SE; four items], Task Strategies [TS; four items], Time Management [TM; three items], Help-seeking [(HS; four items] and Self-Regulation [SR; four items]. The scale items are answered as never (1), rarely (2), occasionally (3), generally (4), always (5). Internal consistency reliability analysis was run for the factors, and Cronbach alpha values were calculated between .632 and .941 . For each subdimension, the internal consistency coefficient was calculated as .92 for Goal Setting, as .95 for Structuring the Environment, as .87 for Task Strategies, as .96 for Time Management, as .93 for Help-seeking, and as .94 for Self-Regulation.
Second-level Confirmatory Factor Analysis (CFA) goodness of fit values were calculated as RMSEA $=.043$, SRMR $=.049$, $\mathrm{NNFI}=.99, \mathrm{GFI}=.89, \mathrm{AGFI}=.86, \mathrm{CFI}=.99$ and $\mathrm{IFI}=.99$. These calculations point out that the scale has a perfect fit.

Web Based Instruction Attitude Scale (WBIAS): This scale was developed by Erdoğan, Bayram and Deniz (2007) to measure students' attitudes towards web-based instruction. WBIAS was designed in the five-point Likert style, and consists of two sub-dimensions; Efficiency of web based instruction [EWBI; 17 items], and Resilience of web-based instruction [RWBI; 9 items]. The scale items are answered as I strongly disagree (1), I do not agree (2), I am indecisive (3), I agree (4), and I totally agree (5). Internal consistency coefficient Cronbach alpha value calculated as .917 for the entire scale. Confirmatory Factor Analysis (CFA) goodness of fit values were calculated as RMSEA $=.036$, SRMR $=.047$, NNFI $=$ $.82, \mathrm{GFI}=.87, \mathrm{AGFI}=.86, \mathrm{CFI}=.91$ and $\mathrm{RFI}=.79$. The results obtained from CFA revealed that the scale factor structure is within acceptable limits.

The data of the research were collected in the fall term of the 2020-2021 educational year. The ethical permission certificate and official permission were obtained for the implementation of the scales mentioned above in the related universities. The scales were applied to the pre-service teachers who were registered at the universities. Consent forms were obtained from the participants and the data collection process was conducted on a voluntary basis. After obtaining the ethical permission certificate and official permission, the scales' questions were transferred into Google Document Form and were sent to the pre-service teachers who were studying in the Turkish language teaching and English language teaching departments of universities that were mentioned above in the sample.

\section{Data Analysis}

In this study, multiple regression analysis was performed to determine whether there was a significant relationship between the dependent and independent variables.

The SPSS 23 [statistical packages for Social Sciences for Windows] (IBM Corp, 2013) was used in the analysis of the research data. Firstly, preliminary analyses were performed to ensure there were no outliers and missing values. For this purpose, frequency values, Mahalanobis distance, Cook's, and leverage values were checked.

In this context, within the scope of the research, 384 data were collected and examined, nine missing values and two outliers were found unacceptable, and were removed from the analyses (Tabachnick \& Fidell, 2013); and 373 data were transferred to the computer. Afterwards normal distribution tests, variance homogeneity, linearity, and multicollinearity analyses were applied. The analyses performed for the distribution of normality and the variation coefficients of the 
data were within the acceptable range. However, skewness and kurtosis values were found to be less than \pm 1.15 , and the histograms distributions were also acceptable. Tabachnick and Fidell (2013) and Pett (1997) considered the skewness and kurtosis values to be within \pm 1.5 limits for normal distribution. In addition, it was recommended that all the methods mentioned above should be evaluated together with the assumption of normal distribution (McKillup, 2012; Stevens, 2009). When the linear regression analysis results of pre-service teachers' online self-regulated learning behaviors and web-based instruction attitude of pre-service teachers variables were examined for each variable, the variance inflation factor (VIF) values were within the range of 1.79-2.97, the CI values were between 10.53 and 19.30, and the tolerance values were quite high. Thus, the multicollinearity assumptions were met for the independent variables. It was determined that the research variables showed a normal distribution.

\section{FINDINGS}

In this section, we (it is) examined whether sub-dimensions of pre-service teachers' online self-regulated learning behaviors [i.e. Goal Setting (GS), Structuring the Environment (SE), Task Strategies (TS), Time Management (TM), Help-Seeking (HS), and Self-Regulation (SR)] significantly predicted web-based instruction attitude [i.e. Efficiency of web-based instruction (EWBI) and resilience of web-based instruction (RWBI)] of pre-service teachers. All scales met the desired standard for reliability of .70. and intraclass correlation coefficient of $95 \%$ confidence interval (Table 2).

Subsequently, multiple regression analysis was created to examine the effect of the online self-regulated learning behaviors of pre-service teachers on EWBI and RWBI. The analysis results of the model are presented in Figure 2, and are detailed in Table 3 and Table 4.

As seen in Table 3, the regression model established to test the effect of online self-regulated learning behavior dimensions [i.e. Goal Setting, Structuring the Environment, Task Strategies, Time Management, Help-seeking, and SelfRegulation] of pre-service teachers on the dimension of EWBI is statistically significant $[\mathrm{F}(6.366)=52506 ; \mathrm{p}<0.001]$. Looking at the explanatory power of these six independent variables in the model, it was found that online self-regulated learning

Table 2: Means, Standard Deviations of Variables Included in the Research Model and Correlations among Core Variables.

\begin{tabular}{|c|c|c|c|c|c|c|c|c|c|c|c|c|c|}
\hline Variables & $N$ & $M$ & $S D$ & $\alpha$ & ICC & $G S$ & $S E$ & TS & $T M$ & $H S$ & $S G$ & $E W B I$ & $R W B I$ \\
\hline GS & 373 & 3.610 & .988 & .874 & .873 & 1 & & & & & & & \\
\hline SE & 373 & 4.136 & .944 & .878 & .876 & $.606^{\star *}$ & 1 & & & & & & \\
\hline TS & 373 & 3.274 & 1.008 & .755 & .742 & $.661^{\star *}$ & $.531^{\star \star}$ & 1 & & & & & \\
\hline $\mathrm{TM}$ & 373 & 3,389 & 1.063 & .795 & .788 & $.720^{* *}$ & $.553^{\star *}$ & $.717^{\star *}$ & 1 & & & & \\
\hline HS & 373 & 3.429 & 1.003 & .723 & .701 & $.438^{\star *}$ & $.511^{\star *}$ & $.508^{\star \star}$ & $.507^{\star *}$ & 1 & & & \\
\hline SG & 373 & 3.307 & 1.072 & .801 & .799 & $.538^{\star \star}$ & $.471^{\star *}$ & $.619^{* *}$ & $.652^{* *}$ & $.606^{* *}$ & 1 & & \\
\hline EWBI & 373 & 3.002 & .968 & .944 & .936 & $.629^{* *}$ & $.399^{* *}$ & $.572^{\star \star}$ & $.521^{\star \star}$ & $.438^{\star *}$ & $.494^{\star *}$ & 1 & \\
\hline RWBI & 373 & 3.295 & 1.022 & .885 & .865 & $-.481^{\star *}$ & $-.286^{\star *}$ & $-.437^{\star *}$ & $-.381^{\star *}$ & $-.269^{* *}$ & $-.364^{\star *}$ & $-.730^{* *}$ & 1 \\
\hline
\end{tabular}

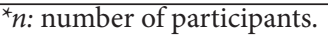

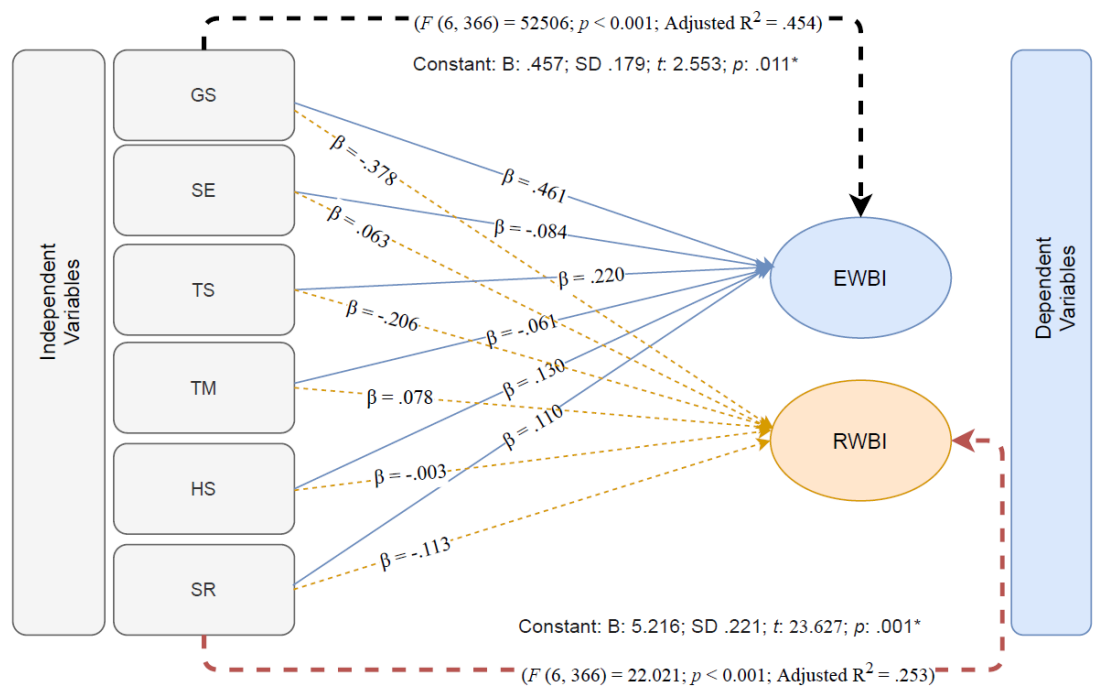

Figure 2: The Regression Model Of The Effect Of Online Self-Regulated Learning Behavior on EWBI and RWBI 
behavior of pre-service teachers total variance explained the EWBI by $45.4 \%$ (Adjusted R2 = .454) collectively. On the other hand, when analyzed in individual significance tests, it was found that the "Goal Setting" $[\mathrm{B}=.457$; SE: .179; $\beta=.461 ; \mathrm{t}$ $(366)=7.546 ; \mathrm{p}<.01]$, “Task Strategies" $[\mathrm{B}=.212$; SE: .058; $\beta$ $=.220 ; \mathrm{t}(366)=3.656 ; \mathrm{p}<.01]$, and "Help-Seeking" $[\mathrm{B}=.126$; SE: .049; $\beta=.130 ; \mathrm{t}(366)=2.540 ; \mathrm{p}<.01]$ sub-dimension had a statistically significant and positive effect on EWBI. The effects of independent variables which had not statistically significant on the dependent variable are listed as "Structuring the Environment" $[\mathrm{B}=-.084 ; \beta=-.084 ; \mathrm{t}(366)=-.1 .575 ; \mathrm{p}>$ .05 ] “Time Management" [ $\mathrm{B}=-.056 ; \beta=-.061 ; \mathrm{t}(366)=-.926$; $\mathrm{p}>.05]$, and "Self-Regulation" $[\mathrm{B}=.099 ; \beta=.110 ; \mathrm{t}(366)=$ .1.926; $\mathrm{p}>$.05]. The findings suggested that predictors, X1 (goal setting), X3 (task strategies), X5 (help-seeking), have the strong predictive power of Y (Efficiency of Web Based Instruction) with reference to both unstandardized coefficients (B) and standardized coefficients $(\beta)$. One-unit standard deviation increase in goal setting would yield a 0.461 standard deviation increase in the predicted EWBI of pre-service teachers with the other variables held constant. Similarly, one-unit standard deviation increase in task strategies, in turn, leads to a .220 standard deviation increase in the predicted EWBI of preservice teachers with the other variables held constant. Lastly, one-unit standard deviation increase in help-seeking would yield a .130 standard deviation increase in the predicted EWBI of pre-service teachers with the other variables held constant. In the regression model conducted $[\mathrm{Yi}=\beta 0+\beta 1 \mathrm{Xi}$ $+\beta 2 \mathrm{X} 2 \mathrm{i}+\ldots+\beta \mathrm{pXpi}+\varepsilon \mathrm{i}]$, the predicted EWBI score is equal to .457 (constant) $+.451^{\star}$ (goal setting) $+-.084^{\star}$ (structuring the environment) $+.212^{*}$ (task strategies) $+-.056^{*}$ (time management $)+.126^{*}$ (help-seeking $)+.099^{*}$ (self - regulation) per one-unit increase in each factor.

As seen in Table 4, the multiple regression was also carried out to investigate whether the effect of online self-regulated learning behavior dimensions [i.e. Goal Setting, Structuring the Environment, Task Strategies, Time Management, Helpseeking, and Self-Regulation] of pre-service teachers could

Table 3: The Regression Model of the Effect of Online Self-Regulated Learning on EWBI

\begin{tabular}{|c|c|c|c|c|c|c|c|c|c|}
\hline \multirow[b]{2}{*}{ Model } & \multicolumn{9}{|c|}{ EWBIa } \\
\hline & $B$ & $S E$ & $\beta$ & $F(6,366)$ & $R$ & $R 2$ & Adjusted R2 & $t$ & $p$ \\
\hline Constantb & .457 & .179 & $\rightarrow$ & & & & & 2.553 & $.011^{\star}$ \\
\hline GS & .451 & .060 & .461 & 52.506 & .680 & .463 & .454 & 7.546 & $.001^{\star}$ \\
\hline SE & -.084 & .053 & -.082 & & & & & -1.575 & .116 \\
\hline TS & .212 & .058 & .220 & & & & & 3.656 & $.001^{*}$ \\
\hline TM & -.056 & .060 & -.061 & & & & & -.926 & .355 \\
\hline HS & .126 & .049 & .130 & & & & & 2.540 & $.012^{\star}$ \\
\hline SR & .099 & .051 & .110 & & & & & 1.926 & .055 \\
\hline $\begin{array}{l}\text { Durbin } \\
\text { Watson }\end{array}$ & .1955 & & & VIF & & & & $1.79-2.97$ & \\
\hline
\end{tabular}

B: Unstandardized Coefficients; SE: Standard Error; $\beta$ : Standardized Coefficients; EWBIa: Efficiency of Web Based Instruction [Dependent Variable]; Constantb: predictors [SR, SE, HS, GS, TS, TM]; VIF: Variance Inflation Factor. Goal Setting (GS), Structuring the Environment (SE), Task Strategies (TS), Time Management (TM), Help-Seeking (HS), and Self-Regulation (SR)

Table 4.: The Regression Model of the Effect of Online Self-Regulated Learning on RWBI

\begin{tabular}{|c|c|c|c|c|c|c|c|c|c|}
\hline \multirow[b]{2}{*}{ Model } & \multicolumn{9}{|c|}{ RWBIa } \\
\hline & $B$ & $S E$ & $\beta$ & $F(6,366)$ & $R$ & $R 2$ & Adjusted R2 & $t$ & $p$ \\
\hline Constantb & 5.216 & .221 & $\rightarrow$ & & & & & 23.627 & $.001^{\star}$ \\
\hline GS & -.391 & .074 & -.378 & 22.021 & .515 & .265 & .253 & -5.297 & $.001^{*}$ \\
\hline SE & .068 & .066 & .063 & & & & & 1.038 & .300 \\
\hline TS & -.208 & .071 & -.206 & & & & & -3.916 & $.004^{\star}$ \\
\hline TM & .075 & .074 & .078 & & & & & 1.015 & .311 \\
\hline HS & -.003 & .061 & -.003 & & & & & -.042 & .966 \\
\hline SR & -.107 & .064 & -.113 & & & & & -1.687 & .092 \\
\hline $\begin{array}{l}\text { Durbin } \\
\text { Watson }\end{array}$ & .1976 & & & VIF & & & & $1.79-2.97$ & \\
\hline
\end{tabular}

B: Unstandardized Coefficients; SE: Standard Error; $\beta$ : Standardized Coefficients; RWBIa: Resilience of Web Based Instruction [Dependent Variable]; Constantb: predictors [SR, SE, HS, GS, TS, TM]; VIF: Variance Inflation Factor 
significantly predict participants' resilience of web-based instruction (RWBI). The results of the regression indicated that the model explained $25.3 \%$ (Adjusted R2 = .253) of the variance and that the model was a statistically significant predictor of RWBI, $[F(6,366)=22.021 ; \mathrm{p}<0.001]$ collectively. Looking at the explanatory power of the unique individual contribution of the predictors in the model, it was found that the "goal setting" $[\mathrm{B}=-.391 ; \mathrm{SE}: .071 ; \beta=-.378 ; \mathrm{t}(366)=-5.297 ; \mathrm{p}<.01]$ and "Task Strategies" $[\mathrm{B}=-.208$; SE: .071; $\beta=-.206 ; \mathrm{t}(366)=-3.916 ; \mathrm{p}<$ .01] sub-dimension had a statistically significant and negative effect on RWBI. The effects of independent variables which did not have statistically significant effects on the dependent variable are listed as "Structuring the Environment" $[\mathrm{B}=.068$; $\beta=.063 ; \mathrm{t}(366)=1.038 ; \mathrm{p}>.05]$ "Time Management" $[\mathrm{B}=.075$; $\beta=.078 ; \mathrm{t}(366)=1.015 ; \mathrm{p}>.05]$, "Help-seeking" $[\mathrm{B}=-.003 ; \beta$ $=-.003 ; \mathrm{t}(366)=-.042 ; \mathrm{p}>.01]$, and "Self-Regulation"” $[\mathrm{B}=$ $-.107 ; \beta=-.113 ; \mathrm{t}(366)=-1.687 ; \mathrm{p}>.05]$. The findings suggested that predictors, X1 (goal setting) and X3 (task strategies) have the strong predictive power of Y (Resilience of Web Based Instruction) with reference to both unstandardized coefficients (B) and standardized coefficients $(\beta)$. One-unit standard deviation increase in goal setting would yield a -.378 standard deviation decrease in the predicted RWBI of pre-service teachers with the other variables held constant. Similarly, oneunit standard deviation increase in task strategies, in turn, leads to a -.226 standard deviation decrease in the predicted RWBI of pre-service teachers with the other variables held constant. In the regression model conducted $[\mathrm{Yi}=\beta 0+\beta 1 \mathrm{Xi}+\beta 2 \mathrm{X} 2 \mathrm{i}+\ldots+$ $\beta \mathrm{pXpi}+\varepsilon \mathrm{i}]$ the predicted RWBI score is equal to 5.216 (constant) $+-.391^{\star}$ (goal setting) $+.068^{\star}$ (structuring the environment) $+-.208^{\star}$ (task strategies) $+.075^{\star}$ (time management) $+-.003^{\star}$ (help-seeking) $+-.107^{\star}$ (self - regulation) per one-unit increase in each factor.

\section{Discussion}

In this part, according to the results, it is discussed by specifically focusing on whether sub-dimensions of students' online self-regulated learning behaviors [i.e. Goal setting, Structuring the Environment, Task Strategies, Time Management, Help-seeking, and Self-Regulation] significantly predicted web-based instruction attitude of students. Afterwards the main findings were interpreted and the limitations of the research were presented.

Finally, the paper was concluded with recommendations for policy, practice, and future research.

In this study, it was found that the "goal setting", "task strategies" and "help-seeking" skills from among the selfregulated learning skills in online environments predicted the web-based instruction attitudes of pre-service teachers, whereas "structuring the environment", "time management" and "self-regulation" skills did not. One of these skills, i.e. the "help-seeking" skill, seems to be related to the individual's motivation with respect to learning and willingness to solve the problems that he/she is likely to encounter in the online environment. In this context, it is not surprising that "help-seeking", as a self-regulated learning skill in online environments, positively affected the pre-service teachers' attitudes towards web-based instruction. It has been reported in the literature that students with self-regulation skills keep their learning motivation high by developing strategies in situations such as stress and pressure (An, Gan \& Wang, 2020). In this context, as another finding of this study, the fact that "goal setting" and "task strategies" skills, which are two of the functional skills, were found to have positively affected the web-based instruction attitudes of pre-service teachers came as no surprise. Along these lines, Littlejohn, Hood, Milligan and Mustain (2016) revealed that students with high-level selfregulated learning skills developed more flexible task strategies and learning approaches, acquiring unique learning styles as a result and that they set goals to improve their knowledge and skills. The ability to set goals is also related to the willingness to learn and has critical importance in the academic and career development of the individual (Atasoy, 2021). There is substantial evidence in the literature that individuals with goal-setting skills set a wide array of goals for themselves in various dimensions whether in relation to their personal lives or their careers and that such individuals use web-based teaching learning environments more effectively (Milligan and Littlejohn, 2016). Similarly, Chumbley et al. (2018) found that there is a highly significant relationship between goal setting and self-regulation skills with respect to web-based education. Additionally, Kizilcec, Pérez-Sanagustín and Maldonado (2017) reported goal setting and strategic planning skills as predictors of students' reaching their personal goals, whereas Jo, Tomar, Ferschke, Rose and Gasevic (2016) revealed that students who set achievable goals for themselves use the MOOC (Massive Open Online Courses) online learning platform for a longer time, and actively participate in activities. In comparison, in this study, self-regulation skills such as "structuring the environment", "time management", and "self-regulation" were not found to have predicted web-based instruction attitudes of pre-service teachers. It is possible that these skills, unlike other self-regulation skills, may not primarily affect academic success, permanent learning and motivation in synchronous online courses. To give an example, students can participate in online education from anywhere, hence "structuring the environment", as a self-regulation skill, may not be of any importance as a predictor, as students can arrange the spatial design where they access online education according to their own conditions. By the same token, "time management", as another self-regulation skill, may not be of any importance as a predictor as well. As a reason, live lessons are recorded in online education, which enables the students to watch the lessons later where they miss a class, and to easily 
repeat the lessons asynchronously at any time and as many times as they want irrespective of whether they miss a class or not. To the contrary of the findings of this study, Chumbley et al. (2018) found that "structuring the environment" and "goal setting" were associated with a high level of self-regulated skills in online courses. The above-mentioned difference between the finding of this study and the finding of Chumbley et al.'s study may be attributed to various factors such as the learning environment designed by the individual, the environment created by the teacher for the online course, technology literacy, ICT skills, and material barriers arising from the teaching environment that hinder learning.

Furthermore, in this study, as opposed to other selfregulated learning skills in online environments which were found not to have predicted resistance to web-based instruction, "goal setting" and "task strategies", two of the selfregulated learning skills in online environments, were found to have predicted the resistance of the pre-service teachers to web-based instruction in the opposite direction, in addition to predicting the web-based instruction attitudes of the preservice teachers. In other words, high levels of these two selfregulated learning skills in online environments can be said to reduce resistance to web-based instruction. For these and other reasons, it has been concluded that these two self-regulated learning skills in online environments are directly related to the process of learning in online education, and can thus directly affect retention in learning, academic success and motivation to learn. It can be said that the decrease in resistance could be an indication that learners may be more willing to use webbased teaching learning systems. As a matter of fact, in another study conducted with students, goal setting and task strategies were found to be directly related to willingness to learn, having an interest in learning, and commitment to learning (Atasoy, 2021). This result indicates that students' willingness to learn, commitment to learning, and motivational dynamics play a critical role in the achievement of permanent learning in the teaching process, whether it is by online or offline education; and it imposes a series of roles and responsibilities with respect to the development of effective teaching policies on various stakeholders ranging from policymakers in education to school administrators, teachers and all other external stakeholders. On the other hand, contrary to the finding of this study, Davis and Neitzel (2011) reported a significantly high relationship between "task strategies" skill as a self-regulated learning skill in online environments and resistance to webbased instruction, meaning that students cannot develop task strategies in online learning environments.

Last but not least, "help-seeking", as another self-regulated learning skill in online environments, was found to have predicted the web-based instruction attitudes of pre-service teachers, but not the resistance of pre-service teachers to web-based instruction. Similar to the results of this study, it was reported in the literature that self-regulated and critical thinking skills supported the willingness of graduate students to seek help concerning online education (Dunn, Rakes, and Rakes, 2014). Accordingly, it would be more likely that students with high web-based instruction attitudes seek help, whereas students with high resistance to web-based instruction do not. It is possible that students with resistance to online education break away from the educational process by alleging many excuses; and therefore, do not seek help. Additionally, some teachers and pre-service teachers constantly compare the efficiency of web-based education with face-to-face education negatively affecting their attitudes towards online education causing them to have resistance to web-based teaching and learning.

\section{Conclusion}

In conclusion, it was found that three of the self-regulated learning skills of the participating pre-service teachers in online environments, i.e. goal setting, task strategies and help-seeking, predicted the attitudes of the pre-service teachers towards web-based instruction significantly and in the positive direction (Hypothesis 1), whereas only two of the self-regulated learning skills of the participating pre-service teachers in online environments, i.e. goal setting and task strategies, predicted the resistance of the pre-service teachers to web-based instruction significantly and in the negative direction (Hypothesis 2).

\section{Suggestions}

Based on the results of this study, it can be considered that self-regulated learning skills have an important place in online education processes. For this reason, in order to increase the qualifications and competencies of students with respect to online education and to ensure that the respective learningteaching processes are maintained effectively, students' selfregulated learning skills in online environments should be developed. It is a known fact that educators have a guiding effect on the development of students' self-regulated learning skills in online environments (Ercoşkun \& Gündoğdu, 2017). Therefore, it is recommended to hold activities that will contribute to the awareness, knowledge, and skills of academicians serving at higher education levels about webbased instruction attitudes and self-regulated learning skills in online environments.

\section{LiMITATION}

There were some limitations to this study. Firstly, the pre-service teachers' attitudes towards, and resistance to, web-based instruction were evaluated only on the basis of self-regulated learning skills in online environments. However, it would have been better to take other stakeholders and 
variables into consideration, given that many stakeholders were involved in and many other variables were at play in the online education process during the pandemic period. To give a few examples, among the stakeholders and variables that are deemed to be crucial for a thorough assessment of the issue are, students' access to online education and their ICT skills, teachers' techno-pedagogical competencies, and families' socio-economic opportunities.

\section{References}

Aji, S. D., Hudha, M. N., Huda, C., Nandiyanto, A. B. D., \& Abdullah, A. G. (2018). The improvement of learning effectiveness in the lesson study by using e-rubric. Journal of Engineering Science and Technology, 13(5), 1181-1189. Retrieved from http:// jestec.taylors.edu.my/Vol\%2013\%20issue\%205\%20May\%20 2018/13_5_4.pdf in 7.7.2021.

Akgün, F. (2018). The investigation of distance education students' attitudes web based instruction and self-efficacy towards online technologies. In 9th International Computer \& Instructional Technologies Symposium-ICITS2015 Full Paper Proceedings. Retrieved from https://drive.google.com/file/d/1AC1by7lCsn E5HBVomLxOHiz8Rn2pvpoc/view in 7.7.2021.

An, Z., Gan, Z., \& Wang, C. (2020). Profiling Chinese EFL students' technology-based self-regulated English learning strategies. Plos one, 15(10). https://doi.org/10.1371/ journal. pone.0240094

An, Z., Wang, C., Li, S., Gan, Z., \& Li, H. (2021). Technology-assisted self-regulated English language learning: Associations with English language self-efficacy, English enjoyment, and learning outcomes. Frontiers in Psychology, 11, 3763. doi: 10.3389/ fpsyg.2020. 558466

Atasoy, R., Özden, C. \& Kara, D. N. (2020). Evaluation of the effectiveness of e-course practices during the Covid-19 pandemic from the students' perspective. Turkish Studies, 15(6), 95-122. https://dx.doi.org/10.7827/TurkishStudies.44491

Atasoy, R. (2021). Öğrencilerin okula bağl1lığ [School commitment of students]. IN N. Özdemir, S. Turan \& Ö. Çoban (Eds.). 21. yüzyıl okullarını yeniden düşünmek [Rethinking 21st century schools] (pp. 335-366). Ankara: Pegem Akademi.

Aydoğan, R. (2018). The effect of values education curriculum based on self regulated learning on students' academic achievements, democratic attitudes, life long learning competency. $\mathrm{PhD}$ Thesis, Adnan Menderes University, Aydın.

Bakioğlu, A. ve Can, E. (2014). Uzaktan Eğitimde Kalite ve Akreditasyon, Ankara, Vize Yayıncılı.

Barnard, L., Lan, W.Y., To, Y.M., Paton, V.O. \& Lai, S.L. (2009). Measuring self-regulation in online and blended learning environments. The Internet and Higher Education, 12, 1-6. https://doi.org/10.1016/j.iheduc.2008.10.005

Bilgiç, H. G., \& Tüzün, H. (2015). Yükseköğretim kurumları web tabanlı uzaktan eğitim programlarında yaşanan sorunlar. Açıköğretim Uygulamaları ve Araştırmaları Dergisi, 1(3), 26-50. Retrieved from https://dergipark.org.tr/en/pub/auad/ issue/3028/42071 in 9.09.2021.

Bradley, R. L., Browne, B. L., \& Kelley, H. M. (2017). Examining the influence of self-efficacy and self-regulation in online learning. College Student Journal, 51(4), 518-530.
Retvieved from https:/www.ingentaconnect.com/content/prin/ csj/2017/00000051/00000004/art00008 in 5.07.2021.

Büyüköztürk, Ş., Çokluk, Ö. \& Köklü, N. (2014) Statistics for Social Sciences. Ankara: Pegem Akademi Publications.

Büyüköztürk, S., Çakmak, E.K., Akgün, Ö.E., Karadeniz, S. \& Demirel, F. (2016). Research methods. Ankara: Pegem Akademi Publications.

Carrillo, C., \& Flores, M. A. (2020). COVID-19 and teacher education: A literature review of online teaching and learning practices. European Journal of Teacher Education, 43(4), 466-487. https:// doi.org/10.1080/02619768.2020.1821184

Chumbley, S., Haynes, J. C., Hainline, M. S., \& Sorensen, T. (2018). A measure of self-regulated learning in online agriculture courses. Journal of Agricultural Education, 59(1), 153-170. https://doi.org/10.5032/jae.2018.01153

Davis, D. S., \& Neitzel, C. (2011). A self-regulated learning perspective on middle grades classroom assessment. Journal of Educational Research, 104(3), 202-215. doi: 10.1080/00220671003690148.

Dunn, K. E, Rakes, G. C., \& Rakes, T.A. (2014). Influence of academic self-regulation, critical thinking, and age on online graduate students' academic help-seeking, Distance Education, 35(1), 75-89, DOI: $10.1080 / 01587919.2014 .891426$

Egeli, S., \& Özdemir, M. B. (2020). An overwiev of the reflections coronavirus pandemic Process on the North Cyprus education system. Education and Society in the 21st Century, 9(27), 779-804. Retrieved from https://dergipark.org.tr/tr/pub/ egitimvetoplum/issue/60522/889516 in 5.7.2021.

Ercoşkun, N. Ç., \& Gündoğdu, K. (2017). A validity and reliability study on the self-regulated learning encouragement scale. Uluslararası Eğitim Programları ve Öğretim Çalışmaları Dergisi, 7(13), 131-146. Retrieved from: http://www.ijocis.com/ index.php/ijocis/article/view/148 in 5.7.2021.

Erdoğan, Y., Bayram, S., \& Deniz, L. (2007). Web based instruction attitude scale: Explanatory and confirmatory factor analyses. Uluslararası İnsan Bilimleri Dergisi, (4)2, 1-14. Retrieved from https://toad.halileksi.net/sites/default/files/pdf/web-tabanliogretim-tutum-olcegi-toad.pdf in 11.7.2021.

Gregory, M. S. J. \& Lodge, J. M. (2015). Academic workload: the silent barrier to the implementation of technology-enhanced learning strategies in higher education. Distance Education, 36(2), 210-230. https://doi.org/10.1080/01587919.2015.1055056.

Gupta, A., \& Pathania, P. (2021). To study the impact of Google Classroom as a platform of learning and collaboration at the teacher education level. Education and Information Technologies, 26(1), 843-857. https://doi.org/10.1007/s10639-020-10294-1

Horzum, M. B. \& Balta, Ö. Ç. (2008). Students' achievement, motivation and computer anxiety level in different web based learning environments. Hacettepe Üniversitesi Eğitim Fakültesi Dergisi. 34, 140-154. Retrieved from https://dergipark.org.tr/ en/download/ article-file/87561 in 5.7.2021.

IBM Corp. (2013). IBM SPSS statistics for Windows (Version 23.0). Armonk, NY: IBM Corp.

Järvelä, S. \& Järvenoja, H. (2011). Socially constructed self-regulated learning and motivation regulation in collaborative learning groups. Teachers College Record, 113(2), 350-374. Retrieved from https://www.tcrecord.org/Content.asp?ContentId=15980 in 5.7.2021.

Jo, Y., Tomar, G., Ferschke, O., Rose, C. P., \& Gasevic, D. (2016). Expediting support for social learning with behavior modeling. 
Retrieved from https://arxiv.org/pdf/1605.02836.pdf in 11.7.2021.

Kanık, M. (2021). Students' perception of and engagement in reactive online education provided during the COVID-19 pandemic. International Online Journal of Education and Teaching (IOJET), 8(2), 1063-1082. Retrieved from https://www.iojet. org/ index.php/IOJET/article/view/1014 in 5.7.2021.

Karasar, N. (2018). Scientific Research Method. Ankara: Nobel Yayın Dağıtım.

Kaya, Z. (2006). Öğretim Teknolojileri ve Materyal Geliştirme. Ankara, Pegem Akademi.

$\mathrm{KeAB}$, (2021). Covid 19 pandemisinin Kuzey Kıbrıs eğitim sistemine etkileri [The effects of the Covid 19 pandemic on the Northern Cyprus education system]. Keab Education Report for 2020, Nicosia. Retrieved from https://www.kibriseab.org/userfiles/ RAPOR(1).pdf in 5.7.2021.

Kizilcec, R. F., \& Halawa, S. (2015). Attrition and achievement gaps in online learning. Paper presented at Learning @ Scale 2015, March, Vancouver. http://dx.doi.org/ 10.1145/2724660.2724680

Korkmaz, O., \& Kaya, S. (2012). Adapting online self-regulated learning scale into Turkish. Turkish Online Journal of Distance Education-TOJDE, (13)1, 52-67. Retrieved from https:// dergipark.org.tr/en/pub/tojde/issue/16899/176119 in 11.7.2021.

KTÖS, (2020). Temel eğitim sistemine bir bakış [An analysis of education system]. Cyprus Turkish Teachers Trade Union, Nicosia. Retrieved from https://ktos.org/wp-content/ uploads/2020/10/KT\%C3\%96S-Temel-E\%C4\%9FitimSistemine-Bak\%C4\%B1\%C5\%9F-2020.pdf in 5.7.2021.

Lawson, M. J., Vosniadou, S., Van Deur, P., Wyra, M., \& Jeffries, D. (2019). Teachers' and students' belief systems about the selfregulation of learning. Educational Psychology Review, 31(1), 223-251. https://doi.org/10.1007/s10648-018-9453-7

Lin, J. W., Huang, H. H., \& Chuang, Y. S. (2015). The impacts of network centrality and self-regulation on an e-learning environment with the support of social network awareness. British Journal of Educational Technology, 46(1), 32-44. https:// doi.org/10.1111/ bjet.12120

Littlejohn, A., Hood, N., Milligan, C., \& Mustain, P. (2016). Learning in MOOCs: Motivations and self-regulated learning in MOOCs. The Internet and Higher Education, 29, 40-48. http:// dx.doi.org/10.1016/j.iheduc.2015.12.003

McKillup, S. (2012). Statistics explained: An introductory guide for life scientists (Second edition). United States: Cambridge University Press.

Mercier, V. B., Scholten, U., Baltensperger, R., Gremaud, L., \& Dabros, M. (2021). Distance Teaching in Chemistry: Opportunities and Limitations. CHIMIA International Journal for Chemistry, 75(1-2), 58-63. https://doi.org/10.2533/chimia.2021.58

Metron Analytics Services, (2021). Covid 19 döneminde KKTC'de ilköğretimde uzaktan eğitim [Distance education in primary education in North Cyprus during Covid 19 period], Education Report, Nicosia.

Milligan, C., \& Littlejohn, A. (2016). How health professionals regulate their learning in massive open online courses. The Internet and Higher Education, 31, 113-121. http://dx.doi. org/10.1016/j.iheduc.2016.07.005

Moos, D. C., \& Bonde, C. (2016). Flipping the classroom: Embedding self-regulated learning prompts in videos. Technology,
Knowledge and Learning, 21(2), 225-242. https://doi. org/10.1007/s10758-015-9269-1

Muhametjanova, G., \& Akmatbekova, A. (2019). The web-based learning environment in general physics course in a Public University in Kyrgyzstan. EURASIA Journal of Mathematics, Science and Technology Education, 15(3), 1-8. https://doi.org/ 10.29333/ejmste/100409

Mukhtar, K., Javed, K., Arooj, M., \& Sethi, A. (2020). Advantages, Limitations and Recommendations for online learning during COVID-19 pandemic era. Pakistan journal of medical sciences, 36(COVID19-S4), 27. https://doi.org/10.12669/pjms.36. COVID19-S4.2785

Nadiahan, M. B. \& Cabauatan, L. I. (2021). Practically ingenious teaching: instructional behavior of teacher education faculty members in a Philippine public state university amidst covid19 pandemic. International Journal of Education, Technology and Science 1(4), 102-118.

Ni, A. Y. (2013). Comparing the effectiveness of classroom and online learning: Teaching research methods. Journal of Public Affairs Education, 19(2), 199-215. https://doi.org/10.1080/15236803.2 013.12001730

Pett, Marjorie A. (1997), Nonparametric Statistic for Health Care Research: Statistic for Small Samples and Unusual Distributions, Sage Public: London, pp.39.

Scull, J., Phillips, M., Sharma, U., \& Garnier, K. (2020). Innovations in teacher education at the time of COVID19: an Australian perspective. Journal of Education for Teaching, 46(4), 497-506. https://doi.org/10.1080/02607476.2020.1802701

Shandra, N., \& Chystiakova, I. (2021). Synchronous and asynchronous distance learning: benefits and limitations. Retrieved from http://eprints.zu.edu.ua/32691/ on 9.12.2021.

Simons, J., Beaumont, K., \& Holland, L. (2018). What factors promote student resilience on a level 1 distance learning module? Open Learning: The Journal of Open, Distance and e-Learning, 33(1), 4-17. https://doi.org/10.1080/02680513.2017.1415140

Simonson, M., Smaldino, S., Albright, M., \& Zvacek, S. (2012). Teaching and learning at a distance: Foundations of distance education. Boston, MA: Pearson.

Smith, S.S. (2006). Web-based instruction: A guide for libraries, (2 nd ed.), American Library Association, Chicago.

Štefančík, R., \& Stradiotová, E. (2021). Obstacles and Limitations in the Use of Modern Technologies in Higher Education During the Covid-19 Pandemic in Slovakia. In 2021 1st International Conference on Technology Enhanced Learning in Higher Education (TELE) (pp. 119-122). IEEE. https://doi.org/10.1109/ TELE52840.2021.9482543

Stevens, J. P. (2009) Applied multivariate statistics for the social sciences (5 b.). New York, NY: Routledge.

Tabachnick, B. G., \& Fidell, L. S. (2013). Using multivariate statistics. Pearson.

Venkatesh, M., \& Sathyalakshmi, S. (2020). Smart learning using personalised recommendations in web-based learning systems using artificial bee colony algorithm to improve learning performance. Electronic Government, an International Journal, 16(1-2), 101-117. https://doi.org/10.1504/EG.2020.105253

Verma, G., Campbell, T., Melville, W., \& Park, B. Y. (2020). Science teacher education in the times of the COVID-19 pandemic. Journal of Science Teacher Education, 31(5), 483-490. https:// doi.org/10.1080/1046560X.2020.1771514 
Wolters C.A., Pintrich P.R., Karabenick S.A. (2005) Assessing academic self-regulated learning. In K.A. Moore \& L.H. Lippman (Eds), What Do Children Need to Flourish? The Search Institute Series on Developmentally Attentive Community and Society, vol 3. Springer, Boston, MA . https:// doi.org/10.1007/0-387-23823-9_16

Yasakc1, A., \& Özdal, H. (2019). An evaluation of the problems encountered by elementary school students while using internet. International Journal of Emerging Technologies in Learning (iJET), 14(22), 204-219. Retrieved from https://www. learntechlib.org/p/217146/ in 11.7.2021.

Zheng, L., Li, X., \& Chen, F. (2016). Effects of a mobile self-regulated learning approach on students' learning achievements and self-regulated learning skills. Innovations in Education and Teaching International, 55(6), 616-624. http://dx.doi. org/10.1080/ 14703297.2016.1259080

Zimmerman, B. J. (2005). Attaining self-regulation: A social cognitive perspective. In M. Boekaerts, P. R. Pintrich, \& M. Zeidner (Eds.), Handbook of selfregulation (pp. 13-39). London: Elsevier Academic Press.

Zimmerman, B. J., \& Schunk, D. H. (2011). Handbook of selfregulation of learning and performance. Abingdon: Taylor \& Francis.

Zimmerman, B. J. (2013). From cognitive modeling to self-regulation: A social cognitive career path. Educational psychologist, 48(3), 135-147. https://doi.org/10.1080/ 00461520.2013.794676 